\title{
Determination of Embedded Depth of Soldier Piles in Pile-Anchor Supporting System in Granite Residual Soil Area
}

\author{
Yiao Liu $\mathbb{D}$, Changming Wang $\mathbb{D}$, Xiaoyang Liu, Ruiyuan Gao, Bailong Li $\mathbb{D}$, \\ and Kaleem Ullah Jan Khan \\ College of Construction Engineering, Jilin University, Changchun 130012, China \\ Correspondence should be addressed to Changming Wang; wangcm@jlu.edu.cn
}

Received 8 January 2021; Revised 31 January 2021; Accepted 6 February 2021; Published 19 February 2021

Academic Editor: Feng Xiong

Copyright (c) 2021 Yiao Liu et al. This is an open access article distributed under the Creative Commons Attribution License, which permits unrestricted use, distribution, and reproduction in any medium, provided the original work is properly cited.

\begin{abstract}
Reasonable depth of pile embedment is one of the key factors for the success of deep foundation pit projects. This paper has taken a deep foundation pit project in a granite residual soil area in Shenzhen as an example and used physical model tests to study the deformation law of the piles and the surrounding soil during the excavation of the deep foundation pit, revealing the variation law of earth pressure in time and space in the pit and then verified it by numerical simulation. The influence of the embedded depth of the pile on the deformation and earth pressure of the deep foundation pit is then explicitly discussed. The study shows that the embedded depth has a significant effect on the deformation and earth pressure distribution of the foundation pit. The earth pressure in front of the pile tends to approach the passive earth pressure as the embedment depth decreases, while the earth pressure behind the pile is in between the Rankine active earth pressure and the static soil pressure; the settlement value and settlement range of the surrounding soil are doubled. The pile displacement increases as the maximum displacement point rises. The maximum displacement of the pile body was used as the basis for determining the instability of the foundation pit. The optimum embedded depth is obtained when the depth of embedment of the pile is $0.22 \mathrm{H}(\mathrm{H}$ is the excavation depth of the foundation pit).
\end{abstract}

\section{Introduction}

There are several types of support systems for deep foundation pits, among which the pile-anchor support structure system is a type of support widely used in engineering. The embedded depth of the soldier piles is an important parameter in the pile-anchor supporting structure system of deep foundation pits. It directly affects the deformation and earth pressure distribution of the supporting structure and also directly affects the economy and safety of the foundation pit supporting system.

Several researchers have conducted studies on the deformation of the foundation pit and the distribution of earth pressure. $\mathrm{Hu}$ et al. [1, 2] used self-made model equipment, simulated the deflection deformation displacement mode of the cantilever pile, and analyzed the soil deformation and failure characteristics and the indoor model test of the passive earth pressure distribution law.
Lei and Zheng [3] have taken a long strip foundation pit supported by a cantilever row of piles as an example, used model tests and finite difference methods to explore the law of load transfer caused by local overexcavation, and initially revealed the local overexcavation. Zuo and Deng [4] conducted research on a certain sluice foundation pit project, an inclinometer was embedded in the row of piles, and a steel bar stress meter was used to monitor the deformation characteristics of the supporting structure of the unequal-length double-row pile foundation pit. The back row was discussed using the standard method. Different pile embedded depths affect the deformation and internal force of the front and rear piles.

Centrifuge model tests are also emerge in model tests. $\mathrm{Gu}$ and Luo [5] conducted a centrifugal model test of a multigroup soldier pile-soil nail wall supporting structure, obtaining the appearance conditions of the soil arching effect between the piles and proposed the final 
morphological analysis model of the soil effect between the piles. A series of centrifuge model tests was conducted to simulate the excavation of a slope at different inclinations and heights, and the effect of the excavation size was taken into consideration [6]. Recently, some new monitoring equipment and test materials have also been applied to the model tests. The RIEGL VZ-400 3D laser scanner was used to monitor the displacement of piles and the soil surface. The low temperature sensitive fiber Bragg grating (FBG) strain sensors were implanted in the model pile to test the axial force of the jacked pile at the pile-soil interface. The qualitative relationship between stress state and deformation and thermal infrared temperature was established from tests. Based on the natural soil as the material by using particle image velocimetry technology, 3D displacement of the soil around a laterally loaded pile was revealed [7-12].

The impact of the embedded depth on the supporting structure of the foundation pit is particularly significant and is extremely sensitive for influencing factors as displacement and settlement. Hyodo et al. [13] performed a three-dimensional analysis of the inadequate length of the soldier piles and obtained the relationship between load and settlement for the inadequate embedded depth of the soldier piles. Cui and $\mathrm{Li}$ [14] discussed the effects of the soldier pile insertion ratio and stiffness on the mechanical properties of the diaphragm wall using the method of field monitoring and numerical simulation correlation verification by using the deepest foundation pit project in Hainan Province as an example. The maximum bending moment of the row pile rises as the insertion ratio increases. However, intuitive physical model tests of the effect of embedded depth of soldier piles on the pit properties are rare. Pile displacement is also difficult to obtain directly. This paper takes a typical row pile and anchor support structure in Futian District, Shenzhen, as an example and uses large-scale model tests as the main research method to study the deformation, soil settlement, and soil settlement of the soldier pile support system under different embedded depths. By comparing the analysis with the finite element numerical simulation, it was revealed that the physical test can simulate the actual engineering conditions, and the research results provide a certain reference for the design optimization of the support structure of the pile foundation pit in the future. The analysis results also suggested that the control value for the embedded depth of the soldier piles should not be less than $0.22 \mathrm{H}$.

\section{Project Overview}

2.1. Architectural Design. The area under study, the "Shenzhen Futian Technology Plaza," is located to the west of Huanggang Interchange on Shennan Road and south of the Shenzhen Electronic School. The area of the building is about $26,000 \mathrm{~m}^{2}$. The study area has 3 high-rise buildings and podiums. The height of the 3 high-rise buildings exceeds $100 \mathrm{~m}$, and the podium is about $15-30 \mathrm{~m}$. The underground structure is composed of three floors. The

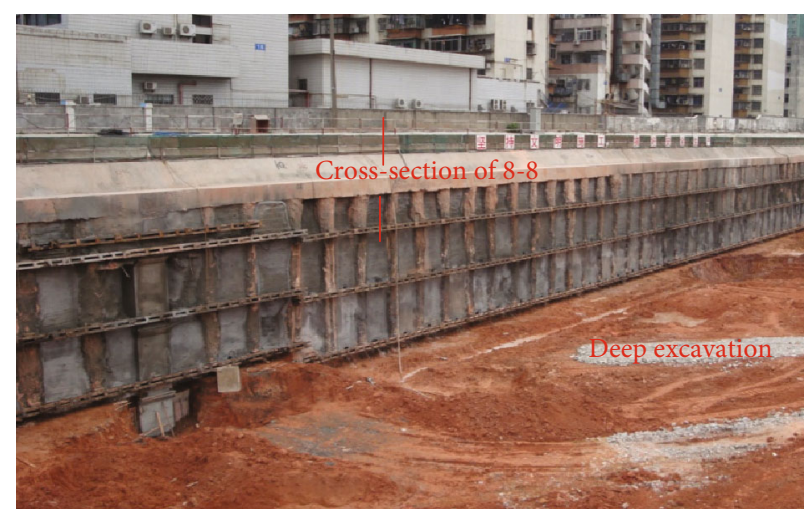

Figure 1: Construction photo of the pile-anchor structure at the west side of excavations.

partial excavation is shallow, and the overall excavation of the foundation pit is about $15 \mathrm{~m}$. The excavation area is about $29270 \mathrm{~m}^{2}$, and the total excavation circumference is about $740 \mathrm{~m}$. The overview of the excavation at the study site is shown in Figure 1.

\subsection{Engineering Geology and Hydrogeological Conditions.}

The topography of the proposed site consists of a sloping remnant mound and a low-lying wash. The mound is located to the west side of the site while the topography gradually decreases from west to east in the gully area. The site has become a construction site for the project after the construction and demolition of houses. A large amount of broken brick walls, concrete blocks, stones, clay soil, and other construction waste piles and earth mounds remain on the ground. In the southeast of the site, a high mound of earth with a large pond (about $40 \mathrm{~m}$ width and $2.40 \mathrm{~m}$ depth) was formed.

The groundwater in the site is mainly divided into two categories according to its deposit medium and burial conditions: (1) Pore water exists in the organic-rich silt layer of the Holocene Alluvium of the Quaternary and in the sand layer of the Upper Pleistocene Alluvium of the Quaternary with clay, which is rich in water content having good permeability and is the main aquifer of the site. (2) The water content and permeability are mainly controlled by the degree of bedrock fracture development; the depth of burial is deeper and is slightly compressive. This layer has less influence on the excavation of the foundation pit. During the survey period, the groundwater level at the site was buried at a depth of $0.4 \mathrm{~m}$ to $3.8 \mathrm{~m}$, with the water table elevation ranging from $3.34 \mathrm{~m}$ to $6.33 \mathrm{~m}$. The groundwater at the site is recharged by atmospheric rainfall, and the direction of runoff flows generally from north to south.

The physical simulation test was carried out based on the representative 8-8 section in the engineering case. The plan view of the foundation pit support structure and a cross-sectional view of the 8-8 section support structure are shown in Figures 2 and 3, respectively. The stratum of the site within the range of the foundation pit 


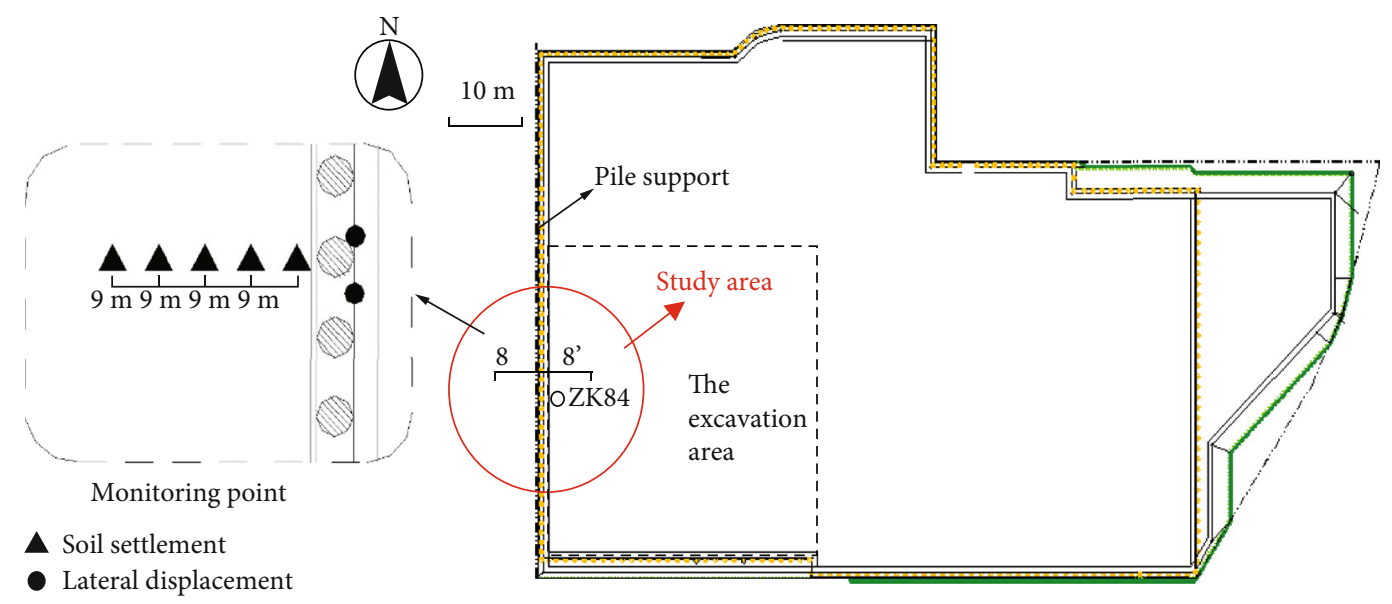

Figure 2: Plan layout of foundation pit support structure.

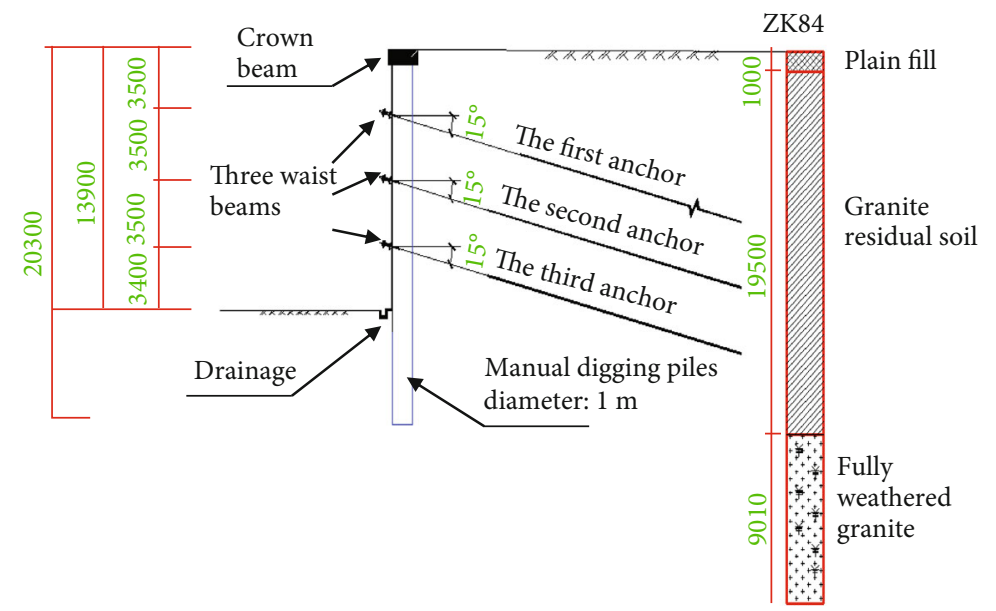

Figure 3: Cross-sectional view of 8-8 of physical model used in the study.

TABLE 1: The detailed information of soil used in the present study.

\begin{tabular}{|c|c|c|c|}
\hline $\begin{array}{l}\text { Stratum } \\
\text { Period }\end{array}$ & Epoch & $\begin{array}{l}\text { Average } \\
\text { thickness }(\mathrm{m})\end{array}$ & Lithology characteristics \\
\hline \multirow{2}{*}{ Quaternary } & $\begin{array}{l}\text { Holocene } \\
\left(\mathrm{Q}_{4}{ }^{\mathrm{ml}}\right)\end{array}$ & 1.0 & $\begin{array}{l}\text { The primary color is brownish-yellow, brownish-red, grey, etc. The main composition is clayey } \\
\text { soil mixed with concrete blocks, bricks, and other construction waste. }\end{array}$ \\
\hline & $\begin{array}{l}\text { Pleistocene } \\
\left(\mathrm{Q}_{3}{ }^{\mathrm{el}}\right)\end{array}$ & 19.5 & $\begin{array}{l}\text { The color is greyish and brown; the top layer is partially gray. The weathered host rock is } \\
\text { mainly coarse-grained granite; the structure of the host rock is clearly visible. }\end{array}$ \\
\hline Cretaceous & $\begin{array}{l}\text { Yanshanian } \\
\left(\gamma \beta^{5} \mathrm{~K}_{1}\right)\end{array}$ & 9.01 & $\begin{array}{l}\text { Brownish-yellow, brownish-grey, rock completely weathered and disintegrated, original rock } \\
\text { structure largely destroyed but still recognizable, with residual structural strength. }\end{array}$ \\
\hline
\end{tabular}

can be divided into the new artificial fill layer, the Quaternary alluvial residual soil layer, and the Mesozoic coarsegrained granite according to the geological era.

The main soil layers in section 8-8 are divided into two types. The upper part is residual gravelly silty clay with a thickness of $19.5 \mathrm{~m}$, and the lower part is fully weathered granite with a thickness of $9.01 \mathrm{~m}$. The specific soils information is shown in Table 1.

2.3. Construction Monitoring. In order to get the real force of the new composite retaining structure in the process of excavation, this project used high precision measuring instruments to monitor the displacement of the main body of the foundation pit, using DSZ2 type automatic level precision for settlement monitoring by arranging monitoring points as shown in Figure 2; the symbol represents the monitoring points of the pile body horizontal displacement while the $\boldsymbol{\Delta}$ symbol represents the surrounding soil settlement monitoring points. The observation work from May 2010 to July 2010 after the pile construction was completed. The maximum displacement of the piles was only $12.6 \mathrm{~mm}$ in the last working condition, which was 


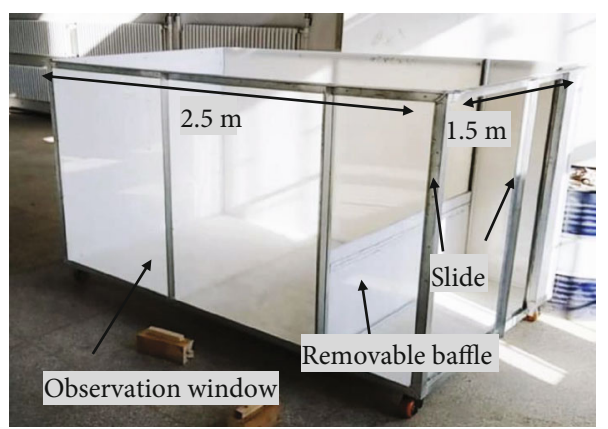

(a)

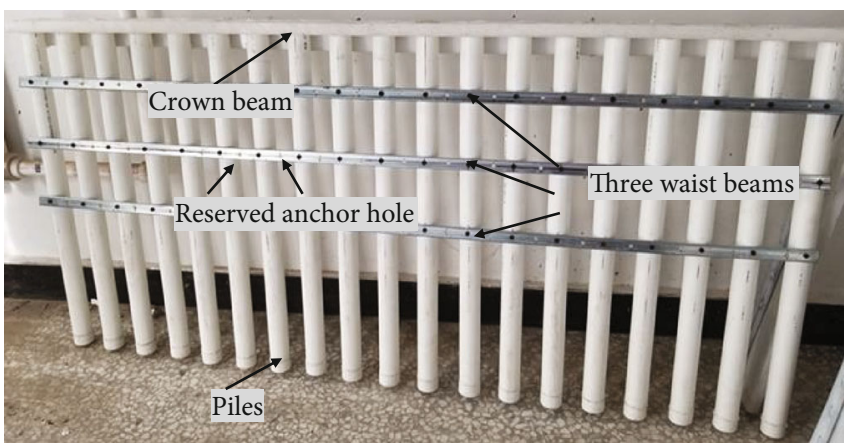

(c)

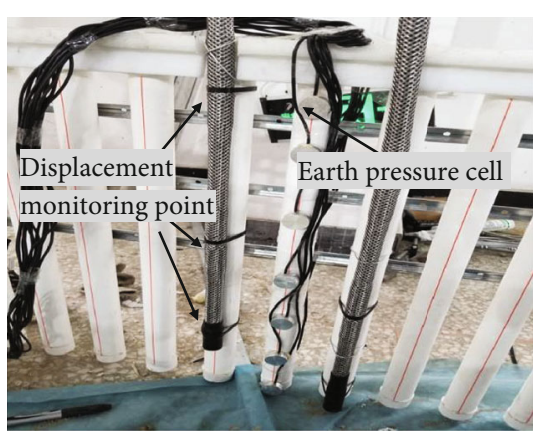

(b)

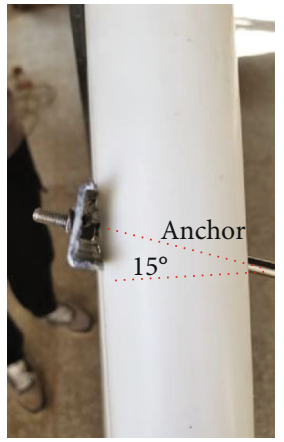

(d)

FIgURE 4: The preparatory work: (a) model box; (b) monitoring equipment; (c) soldier piles; (d) simulation of anchor.

TABLE 2: The proportions and properties of similar materials.

\begin{tabular}{lcccc}
\hline Number & Similar soil mass 1 & Granite residual soil & Similar soil mass 2 & Fully weathered granite \\
\hline Bentonite $(\%)$ & 30 & - & 26 & - \\
Sand $(\%)$ & 70 & - & 74 & - \\
Density $\left(\mathrm{kg} / \mathrm{m}^{3}\right)$ & 1.58 & - & 1.56 & - \\
Moisture content $(\%)$ & 20 & - & 0.22 & - \\
Cohesion $(\mathrm{kPa})$ & 1.365 & 25 & 0 & 30 \\
Friction angle $\left({ }^{\circ}\right)$ & 23.6 & 20 & 28 & 72 \\
Variable modulus $(\mathrm{MPa})$ & 0.87 & 22.1 & 2.34 & 19.5 \\
Weight $\left(\mathrm{kN} / \mathrm{m}^{3}\right)$ & 18.56 & 19.5 & 19 & 4.8 \\
Thickness $(\mathrm{m})$ & 0.68 & 20.4 & 2.34 & \\
\hline
\end{tabular}

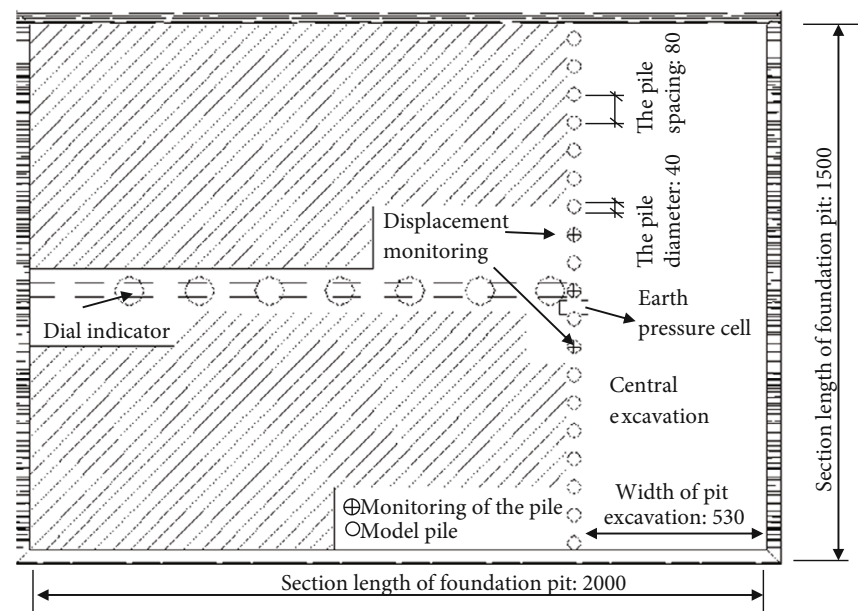

Figure 5: Overview of the physical model design. 


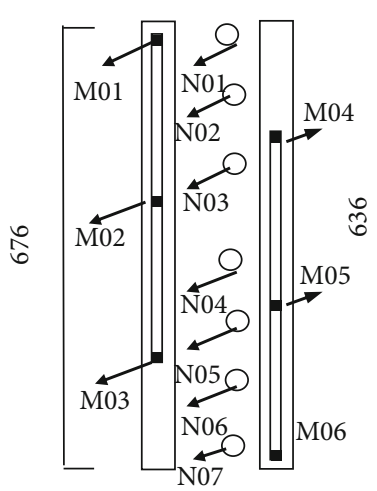

The embedded depth of $0.41 \mathrm{H}$

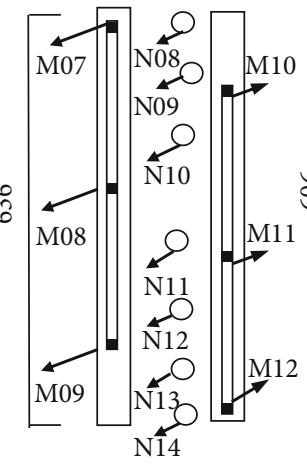

The embedded depth of $0.33 \mathrm{H}$

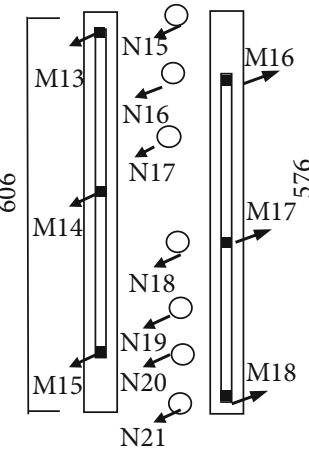

The embedded depth of $0.27 \mathrm{H}$

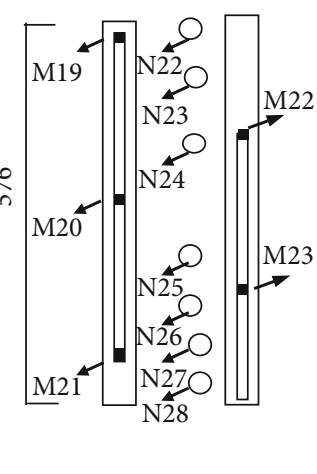

The embedded depth of $0.21 \mathrm{H}$

FIgure 6: The location of the displacement sensor and earth pressure cell.

TABLE 3: The steps of test preparation.

\begin{tabular}{lr}
\hline Step & Test preparation \\
\hline 1 & Install displacement sensor and keep the vertical distance of the displacement monitoring points behind the pile with interval of \\
2 & $12.5 \mathrm{~cm}$. \\
3 & Install earth pressure cell according to the location of the waist beams. \\
4 & Treembedded piles and anchor rods. Prebury the soil to the corresponding height, install the anchor rod, and fix it with screws until the \\
5 & excavation reaches the corresponding position to simulate the actual anchor rod construction stage.
\end{tabular}

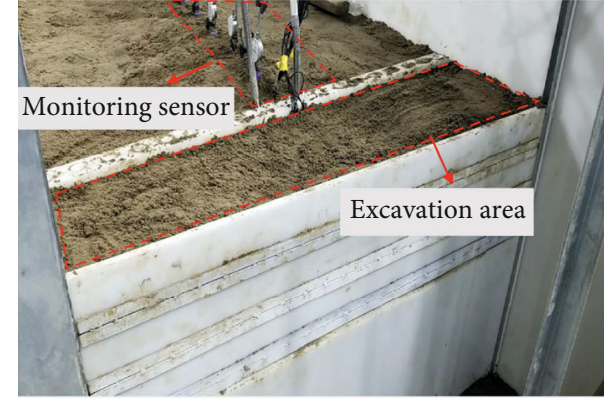

Figure 7: The physical model after the completion of embedded work.

much less than the requirements of the foundation support code. This showed that a reasonable reduction in the depth of embedment of the soldier piles is necessary.

\section{Test Methods}

\subsection{Physical Model Test}

3.1.1. Test Preparation. The customized model box for a physical model test is shown in Figure 4, the plan size of which is $2.5 \mathrm{~m} \times 1.5 \mathrm{~m}$, and the height is $1.5 \mathrm{~m}$. The prototype supporting pile corresponding to the test is a pipe pile with a diameter of $1200 \mathrm{~mm}$ and a pile length of $20.3 \mathrm{~m}$ with a modulus of elasticity of $30 \mathrm{GPa}$. The model pile material is a PC tube with a diameter of $40 \mathrm{~mm}$, length of $676 \mathrm{~mm}$, and bending modulus of $2 \mathrm{GPa}$. The anchor rod is a steel bar of PRB 300, the length of the first layer is about $25 \mathrm{~m}$, and the length of the second and third layers is $22 \mathrm{~m}$ with an elastic modulus of $2 \mathrm{GPa}$. The test bolts are simulated by aluminum rods, the lengths of which are $1.5 \mathrm{~m}, 0.7 \mathrm{~m}$, and $0.7 \mathrm{~m}$ with an elastic modulus of $0.72 \mathrm{GPa}$. The geometric similarity ratios of the bolt models are all $C_{1}=30$, and the elastic modulus similarity ratios are 15 and 2.7.

The test soil material was composed of bentonite and quartz sand in proportion to simulate granite residual soil and fully weathered granite [15]. The corresponding internal friction angle similarity ratios were 0.85 and 0.89 , which are close to 1 . The similarity ratio of cohesion and deformation modulus is close to 30 . The ratio and properties of similar soil materials are shown in Table 2. The crown beam in the supporting structure system is simulated by a $20 \mathrm{~mm}$ thick PPR plate and welded to the row of piles to ensure the rigidity of the connection between the row of piles and the crown beam. The anchor rod and the horizontal line are bolted at $15^{\circ}$, which may be in line with the actual situation.

3.1.2. Test Data Collection. The earth pressure is measured by the earth pressure cell adjusted on the PV pipe, with a range of $0 \sim 50 \mathrm{kPa}$ and a size of $\phi 20 \mathrm{~mm} \times 8 \mathrm{~mm}$. The earth pressure cell was fixed at different depths along the 


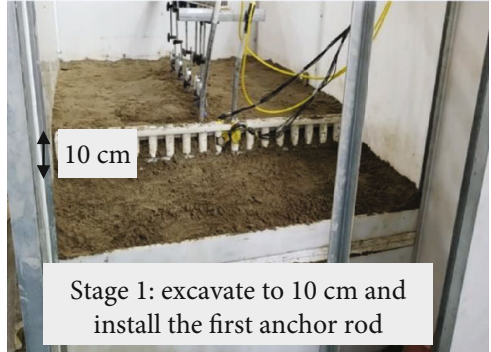

(a)

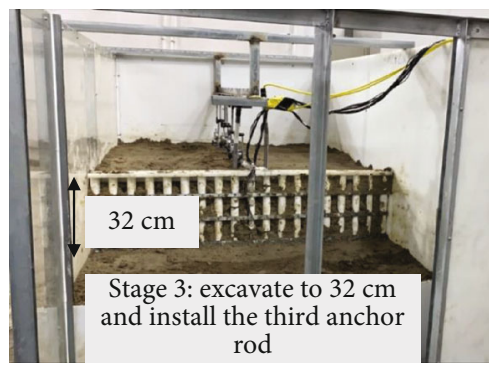

(c)

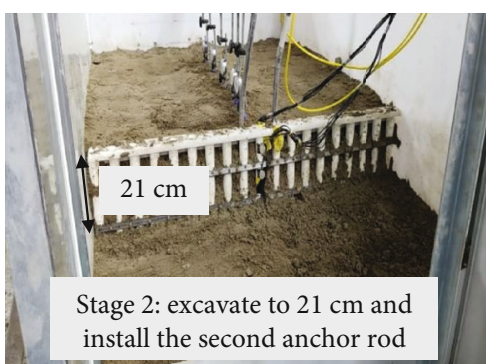

(b)

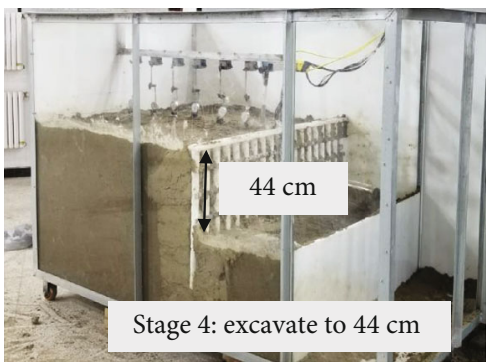

(d)

FIGURE 8: Excavation stage of foundation pit: (a) stage 1; (b) stage 2; (c) stage 3; (d) stage 4.

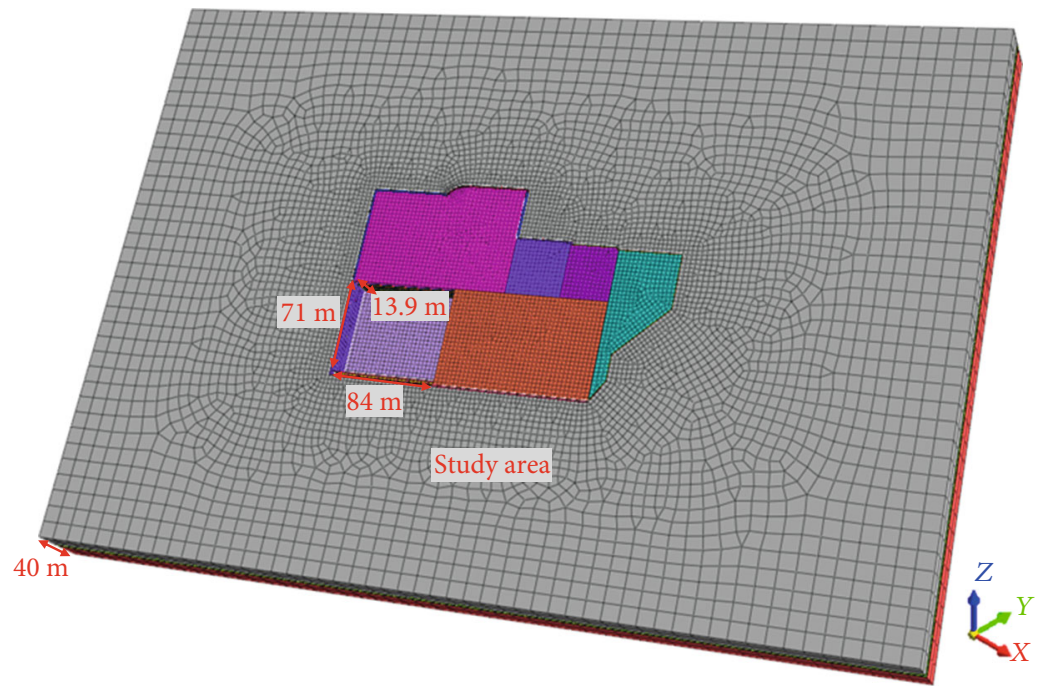

FiguRE 9: FEM mesh used in numerical simulations.

TABLE 4: Geotechnical parameters used in the study.

\begin{tabular}{lcccccccccccc}
\hline Parameter & $\alpha$ & $E_{50}^{\text {ref }}(\mathrm{MPa})$ & $E_{\mathrm{oed}}^{\text {ref }}(\mathrm{MPa})$ & $E_{\mathrm{ur}}^{\text {ref }}(\mathrm{MPa})$ & $C(\mathrm{kPa})$ & $\Phi\left(^{\circ}\right)$ & $\sigma^{\text {ref }}(\mathrm{kPa})$ & $n$ & $R_{f}$ & $K_{0}$ & $m$ & $\Psi\left(^{\circ}\right)$ \\
\hline Plain fill & 1.3 & 6.5 & 6.5 & 39 & 8 & 12 & 100 & 0.44 & 0.9 & 0.79 & 0.7 & 0 \\
Gravel clay & 1.3 & 22.1 & 22.1 & 66.3 & 25 & 22 & 100 & 0.41 & 0.9 & 0.63 & 0.7 & 0 \\
Fully weathered granite & 2.0 & 72 & 72 & 216 & 30 & 25 & 100 & 0.4 & 0.9 & 0.58 & 1 & 0 \\
\hline
\end{tabular}

vertical centerline area of the PC pile [16-19]. During the test, the mechanical dial indicators were used to monitor the settlement value of the soil, to observe and record the change in the settlement of the soil mass after each working stage. The deformation monitoring sensors were used to monitor the displacement of the pile body in real time. The monitor can observe the displacement of one point every $25 \mathrm{~cm}$. The two piles were arranged staggered along the pile body at intervals of $12.5 \mathrm{~cm}$. In this way, the displacement data of 6 points was monitored at the same time. The overview of the physical model design is shown in Figure 5. In Figure 6, " $M$ " represents the 


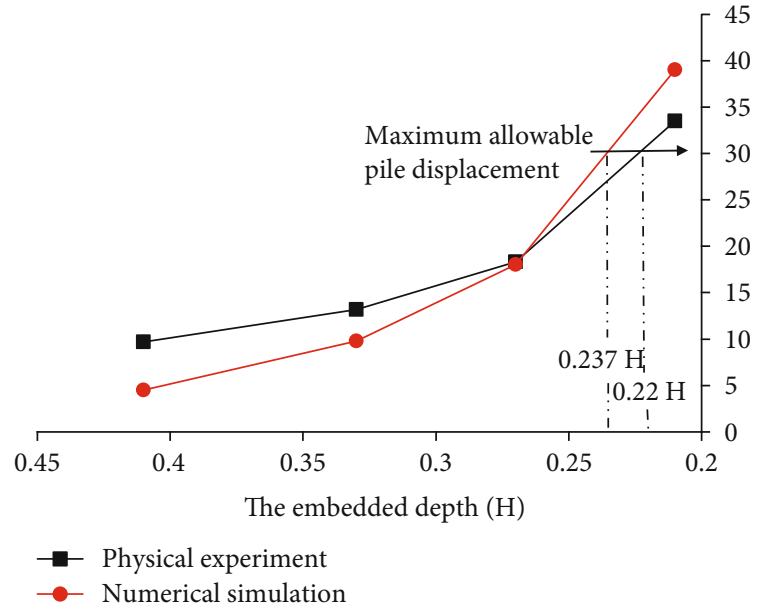

(a)

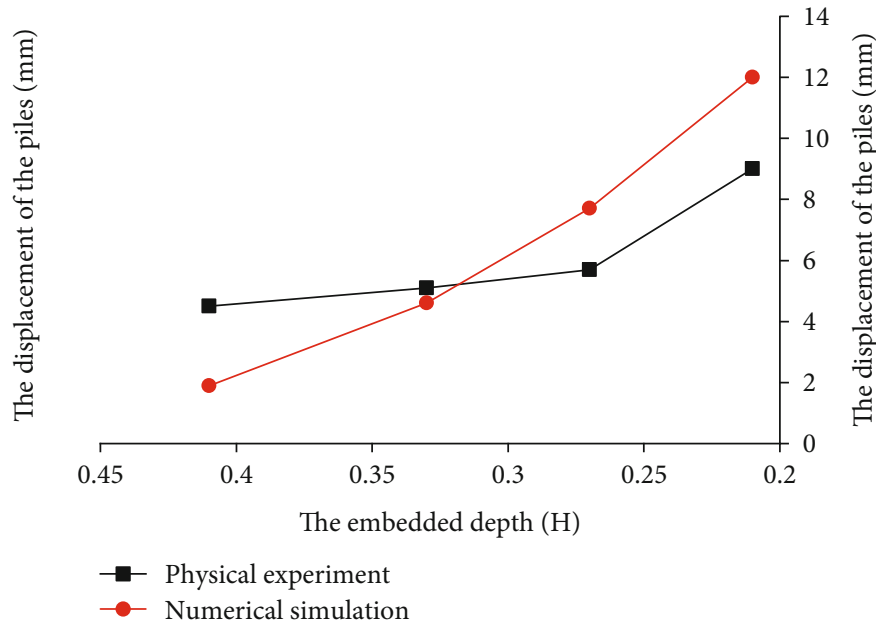

(b)

Figure 10: Comparison between the model test and numerical simulations: (a) comparison of the displacement; (b) comparison of the soil settlement.

deformation monitoring sensor and "N" represents the earth pressure cell. The excavation process of the foundation pit was completely in accordance with the actual foundation pit excavation. The steps of the test preparation are shown in Table 3.

3.1.3. Test Stages. The excavation process of the foundation pit is carried out completely in accordance with the prototype of the foundation pit. It is divided into 4 stages:

(i) Stage 1: excavate to the depth of the first anchor rod, $10 \mathrm{~cm}$ in depth; installed the first anchor rod (Figure 8(a));

(ii) Stage 2: excavation to the second anchor rod setting, $21 \mathrm{~cm}$ in depth; installed the second anchor rod (Figure 8(b));

(iii) Stage 3: excavation to the depth of third anchor rod, with a depth of $32 \mathrm{~cm}$, installed the third anchor rod (Figure 8(c));

(iv) Stage 4: excavation to the bottom of the foundation pit with a depth of $44 \mathrm{~cm}$ (Figure 8(d)).

During the excavation simulation process as discussed above, the ground surface deformation, earth pressure behind the pile, and pile displacement are recorded in real time. So far, the whole process of simulation excavation test of a pile embedded length is over. Moreover, the embedded depth was changed, and the aforementioned stages were repeated to obtain the displacement and earth pressure distribution laws under different pile embedded depths.

3.2. Numerical Simulation Analysis. The numerical model used in the present study by taking the Shenzhen soldier pile foundation pit as the prototype was established in
Midas for numerical analysis as shown in Figure 9. The study area is $71 \mathrm{~m} \times 84 \mathrm{~m}$, consistent with the foundation pit site, and the excavation depth is $13.9 \mathrm{~m}$. A diaphragm wall of equal stiffness is used to replace the soldier piles for the convenience of simulation. The thickness of the diaphragm wall was taken as $0.77 \mathrm{~m}$ according to the principle of equal stiffness. The model soil is simulated by a modified Mohr-Coulomb model, which is more sensitive to the excavation stress level and path of the foundation pit and is more in line with the actual conditions of the test $[16,20,21]$. The soil parameters used in numerical simulations are shown in Table 4.

\section{Comparative Analysis of Results}

Numerical simulation was performed according to the working stages of the test from 1 to 4 through Midas finite element software, and the results are compared with the test results. Figure 10 shows the relationship between the maximum displacement of the pile body and the embedded depth in the case of stage 4 . In the numerical simulation, when the embedded depth of the soldier piles was $0.27 \mathrm{H}$, the maximum displacement of the pile body was $12.7 \mathrm{~mm}$, which corresponds to the maximum displacement of the pile body in the physical test of $13.1 \mathrm{~mm}$. The maximum displacement of the pile body corresponding to the numerical simulation and the physical test was $36.8 \mathrm{~mm}$ and $32.1 \mathrm{~mm}$, respectively, when the embedded depth was reduced to $0.2 \mathrm{H}$, which are very close. According to the technical code for retention and protection of excavations in Shenzhen city [22], the maximum horizontal displacement of the pile body should not exceed $30 \mathrm{~mm}$, and the minimum embedded depths which were obtained by numerical simulation and physical test were $0.237 \mathrm{H}$ and $0.22 \mathrm{H}$, respectively. 


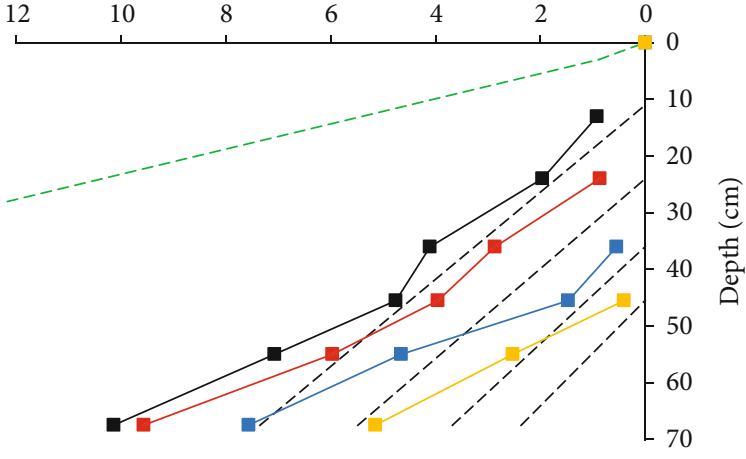

Earth pressure $(\mathrm{kPa})$

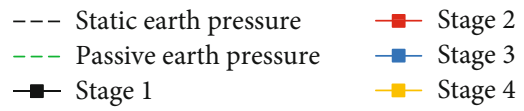

(a)

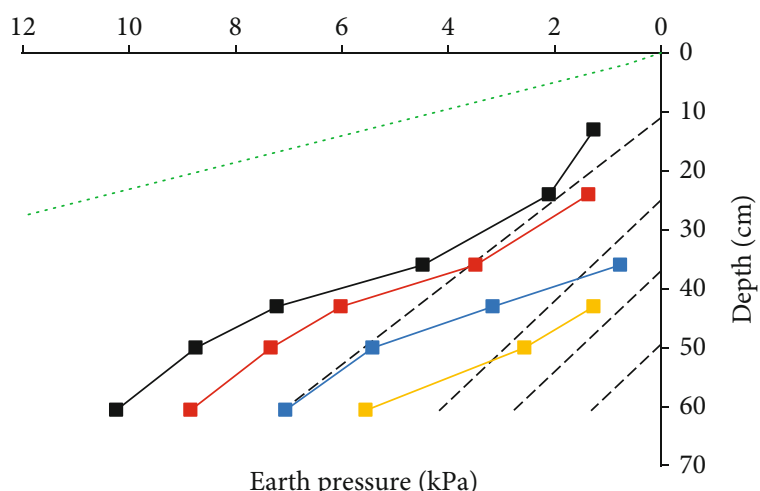

Earth pressure $(\mathrm{kPa})$

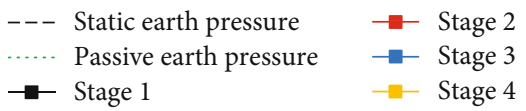

(c)

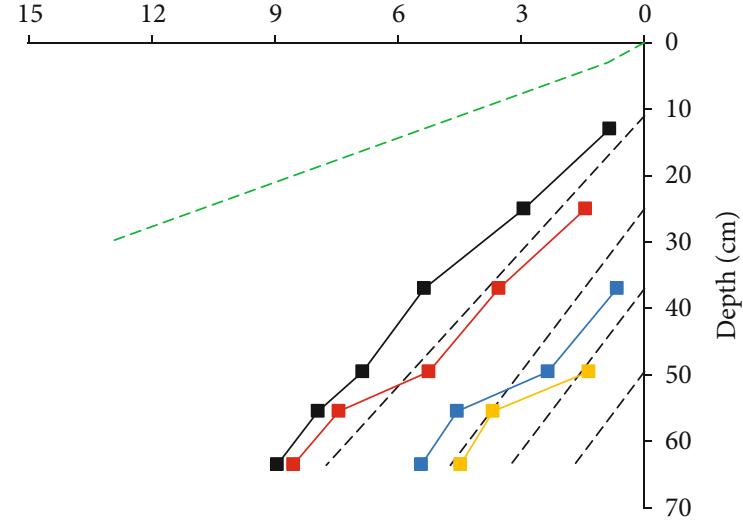

Earth pressure $(\mathrm{kPa})$

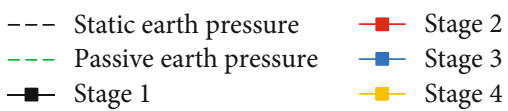

(b)

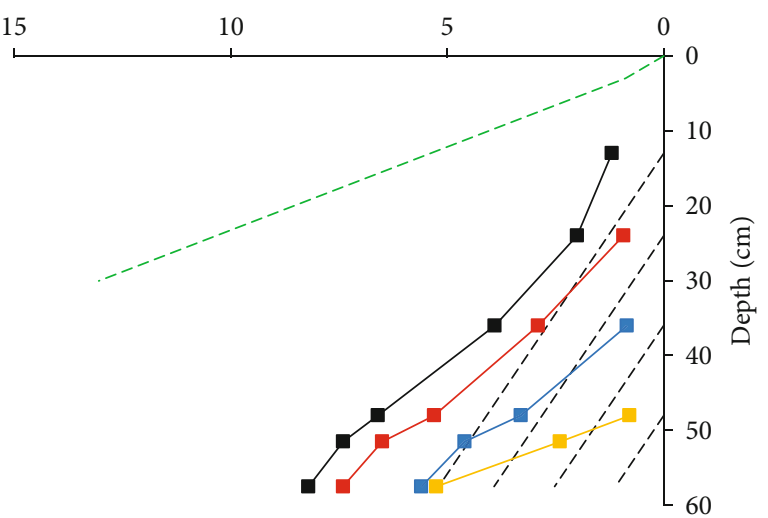

Earth pressure $(\mathrm{kPa})$

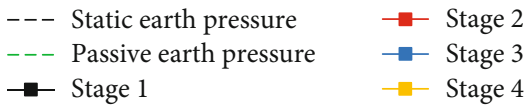

(d)

FIGURE 11: (a) Earth pressure in the front of the wall of $0.41 \mathrm{H}$; (b) earth pressure in front of the wall of $0.33 \mathrm{H}$; (c) earth pressure in front of the wall of $0.27 \mathrm{H}$; (d) earth pressure in front of the wall of $0.21 \mathrm{H}$.

The maximum settlement value of the two simulations increases with the increase of embedded depth of surrounding soil. The maximum settlement values of the surrounding soil of the numerical simulation and the physical test were $0.42 \mathrm{~mm}$ and $0.58 \mathrm{~mm}$, respectively, when the embedded depth was reduced to $0.33 \mathrm{H}$. The maximum settlement value has suddenly increased, up to $14 \mathrm{~mm}$ and $9 \mathrm{~mm}$, respectively, when the embedded depth was $0.21 \mathrm{H}$. In general, the pile displacement and surrounding soil settlement obtained by numerical simulation are close to the model test results.

\section{Optimal Embedding Analysis}

The earth pressure, pile lateral displacement, and vertical deformation of the ground were obtained $(\mathrm{H}$ is the exca- vation depth of the foundation pit) with the different embedded depths of the soldier piles $(0.41 \mathrm{H}, 0.33 \mathrm{H}$, $0.27 \mathrm{H}$, and $0.21 \mathrm{H}$ ) through the excavation physical test.

5.1. Earth Pressure Analysis. It can be concluded from Figures 11 and 12 that the interior of the foundation pit belongs to the passive earth pressure area, and the outer side of the foundation pit belongs to the active earth pressure area [20]. The embedded depth and excavation depth have significant effects on the earth pressure in front of the pile. The earth pressure in front of the pile decreases significantly as the excavation depth increases, but both are greater than the static earth pressure. It can be seen that the interior of the foundation pit belongs to the passive earth pressure zone, which is also consistent with the displacement law of the pile. The earth pressure tends to 

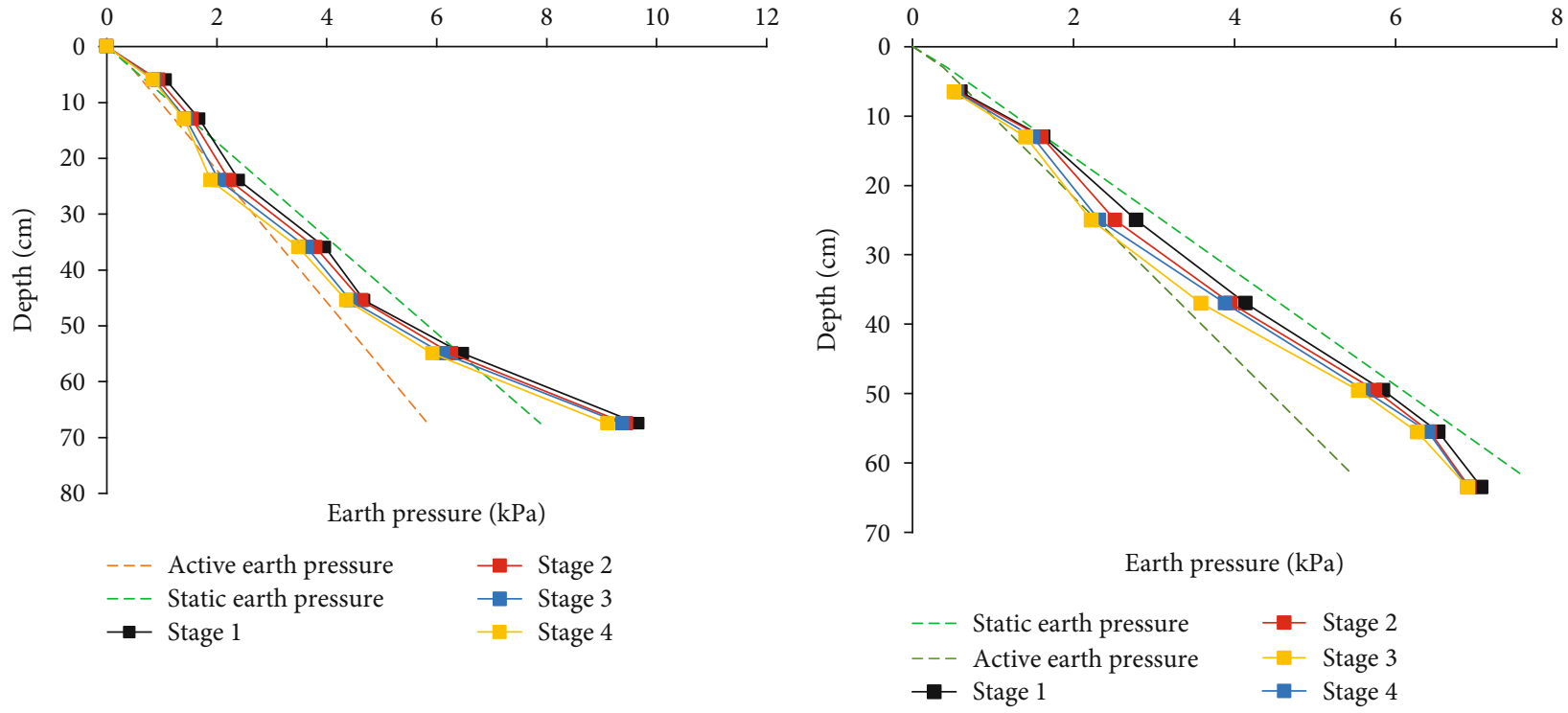

(a)

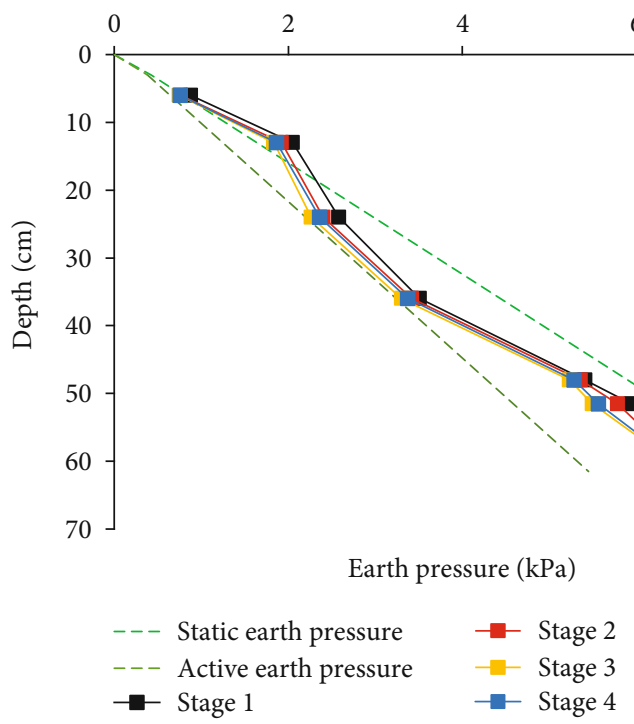

8

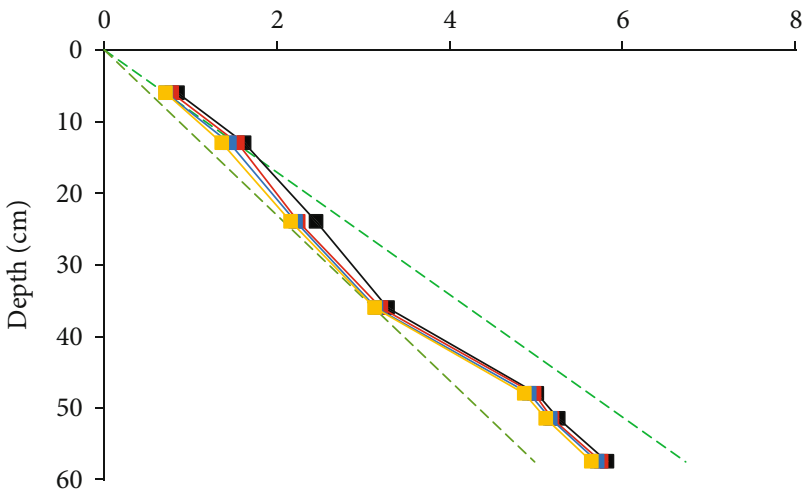

Earth pressure $(\mathrm{kPa})$

(c)

(d)

Figure 12: (a) Earth pressure behind the wall of $0.41 \mathrm{H}$; (b) earth pressure behind the wall of $0.33 \mathrm{H}$; (c) earth pressure behind the wall of $0.37 \mathrm{H}$; (d) earth pressure behind the wall of $0.21 \mathrm{H}$.

approach the limit of passive earth pressure as the embedded depth decreases. The active earth pressure behind the pile increases almost linearly with the depth, but with the increase of the excavation depth, the earth pressure decreases, which is caused by the displacement of the pile body into the pit. The earth pressure behind the pile is between the Rankine active earth pressure and the static earth pressure in each group of tests $[23,24]$. The earth pressure decreases more obviously when the embedded depth was reduced from $20 \mathrm{~cm}$ to $10 \mathrm{~cm}$. The pile body in the embedded section caused a sudden increase in earth pressure when the earth pressure of the pile body has reached the limit of active earth pressure. This is because of the small displacement of the supporting pile below the excavation surface and the dense soil. Hence, it is difficult to reach the active limit state.

5.2. Displacement Analysis. Figure 13 shows the measured values of the horizontal displacement of the pile body under different soldier pile embedded depths and different working stages.

It can be seen in Figure 13 that as the excavation depth increases, the horizontal displacement of the pile body increases. Among these, the fourth stage has the greatest impact on the pile displacement. The maximum displacement value decreases with the increase of 

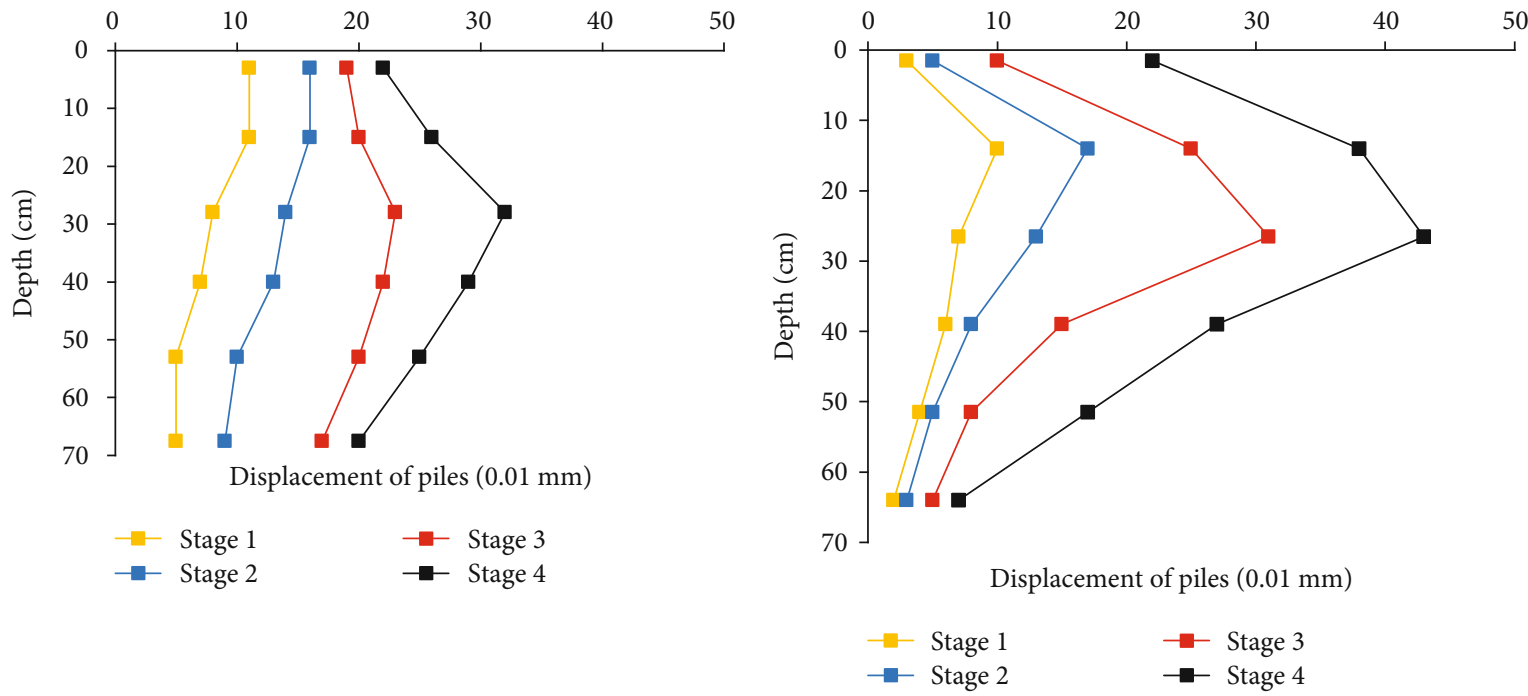

(a)
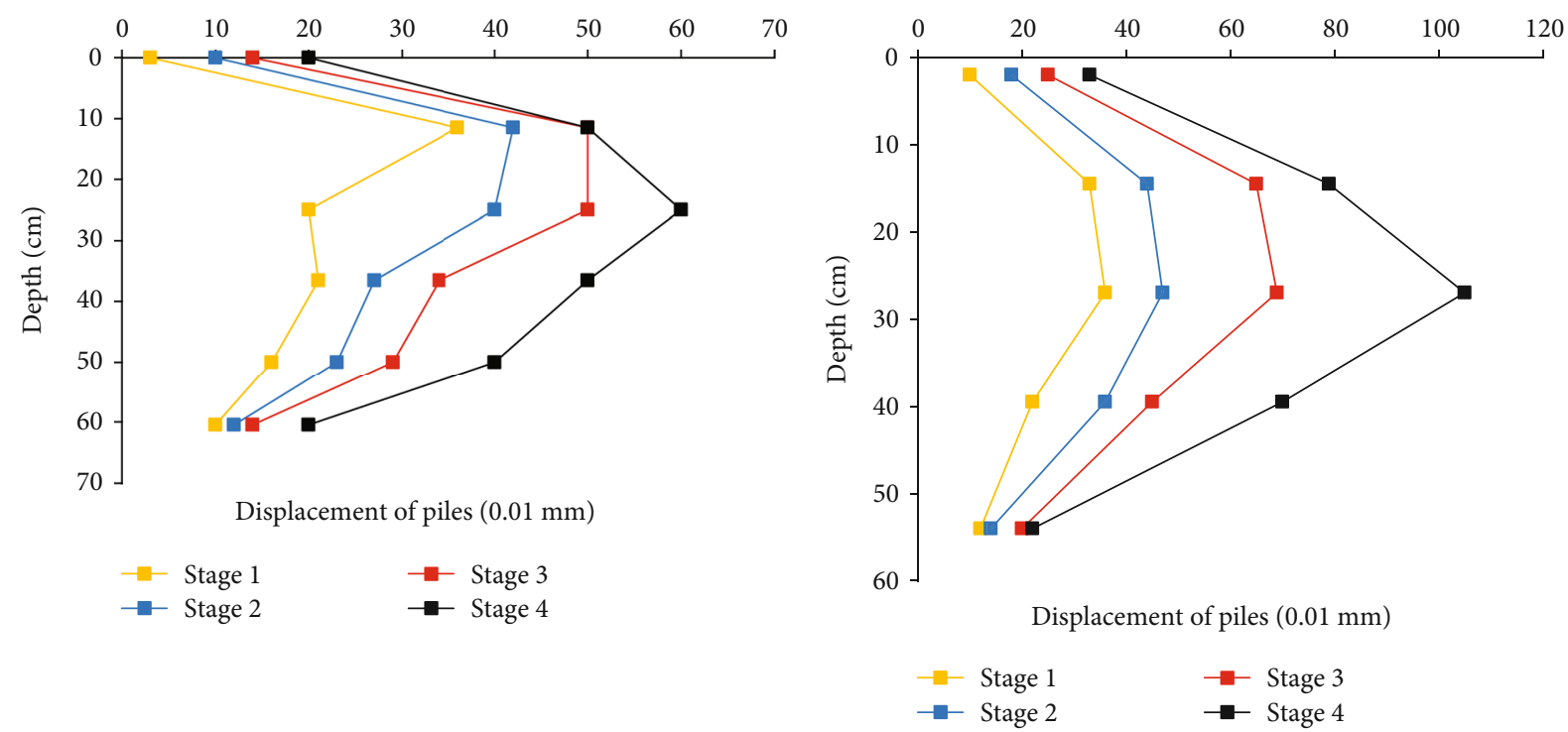

(c)

(d)

Figure 13: (a) Pile displacements of $0.41 \mathrm{H}$; (b) pile displacements of $0.33 \mathrm{H}$; (c) pile displacements of $0.27 \mathrm{H}$; (d) pile displacements of $0.21 \mathrm{H}$.

excavation depth. The smaller the embedded depth, the greater will be the final horizontal displacement of the pile body under the working stages of different embedded depths of soldier piles. The horizontal displacement of the pile body at $0.2 \mathrm{H}$ embedded depth reached $0.19 \% \mathrm{H}$, which is very close to the average horizontal displacement value of $0.13 \% \mathrm{H}$ for soldier pile support structures in southern China [16]. In the last test, the displacement exceeded up to $1.2 \mathrm{~mm}$ and was converted to $36 \mathrm{~mm}$ according to the similarity coefficient, which does not meet the maximum horizontal pile displacement of $30 \mathrm{~mm}$ specified in the "Technical Regulations for Building Foundation Pit Support” JGJ120-2012 [22]. The pile displacement below the excavation surface of the foundation pit was significantly reduced, which shows that the soil at the bottom has a good embedding effect. The maximum displacement first appeared at $20-30 \mathrm{~cm}$. The positions of the maximum displacement of the pile body were about $0.37 \mathrm{H}, 0.48 \mathrm{H}, 0.46 \mathrm{H}$, and $0.50 \mathrm{H}$, with the continuous decrease of the embedded depth. It can be seen that with the decrease of the embedded depth, the position of the maximum displacement shows a downward trend [16].

5.3. Ground Settlement behind Piles. Figure 14 shows the measured values of the soil surface settlement behind the piles under different soldier pile embedded depths and different working stages. It can also be seen from Figure 14 that the settlement of the soil was first increased and then decreased, showing a groove shape. The settlement of the soil behind the pile gradually increased with the progress of excavation, and the maximum settlement position appeared at $0.3 \mathrm{H}-0.7 \mathrm{H}$ from the side of the pit. The final 


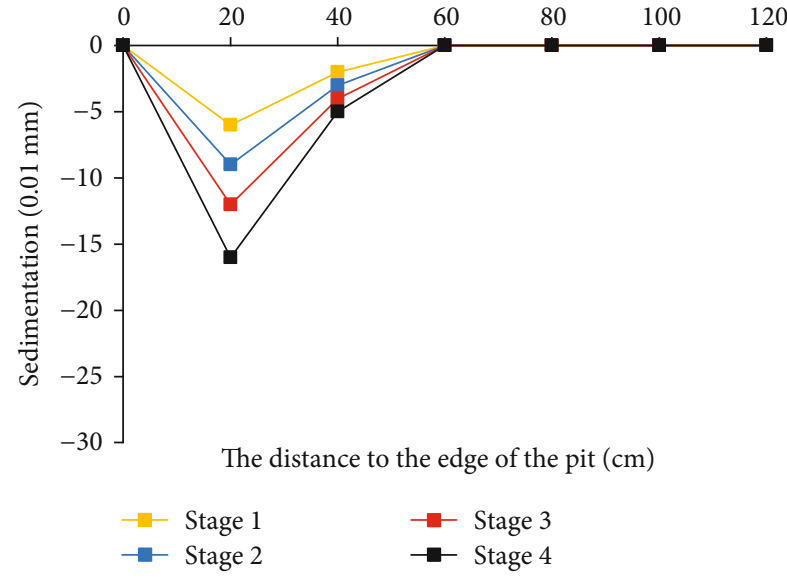

(a)

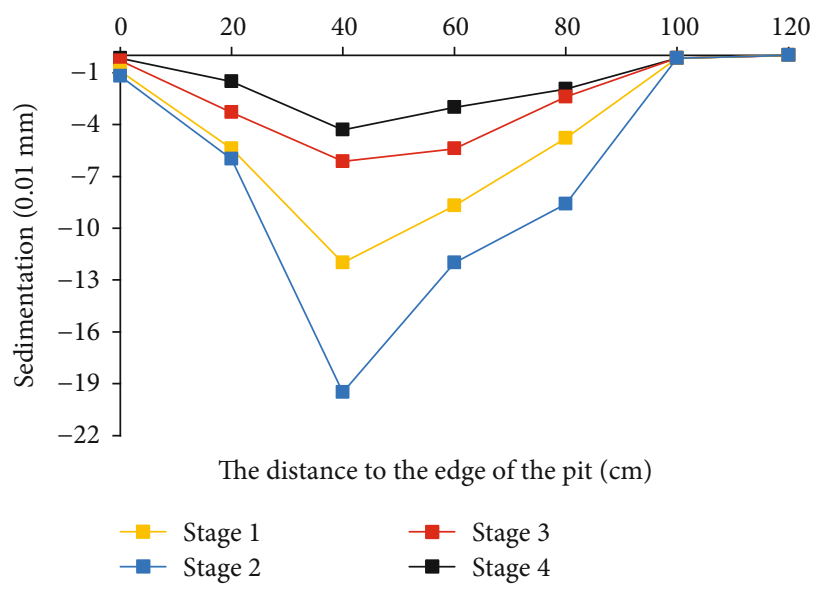

(c)

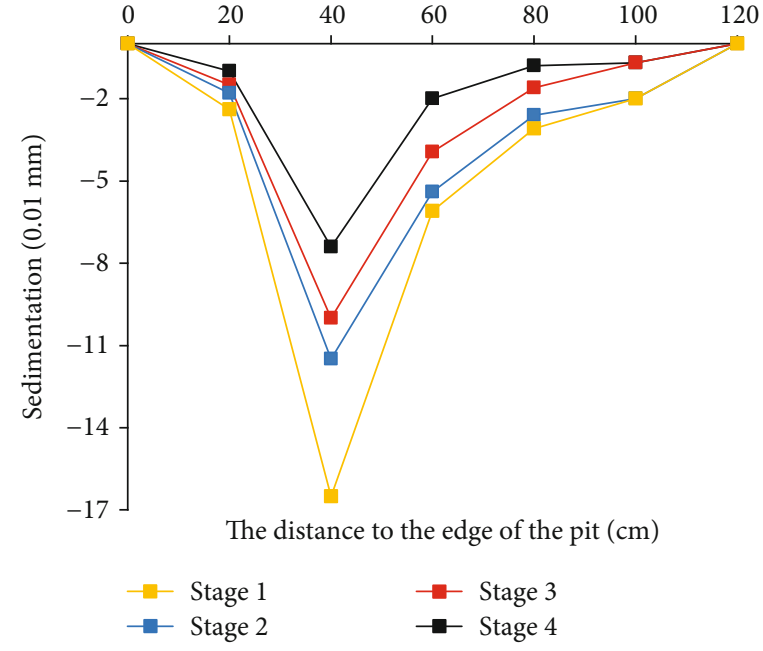

(b)

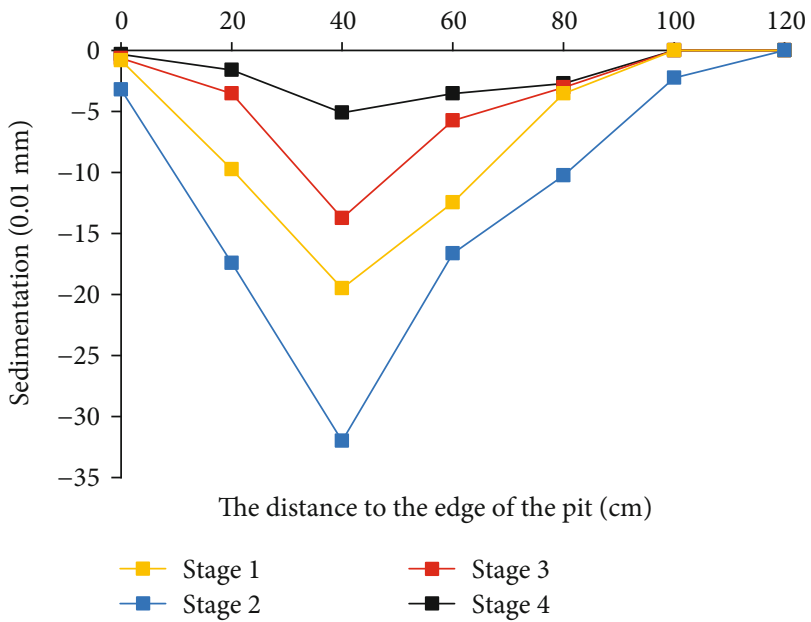

(d)

Figure 14: (a) Soil settlement of $0.41 \mathrm{H}$; (b) soil settlement of $0.33 \mathrm{H}$; (c) soil settlement of $0.27 \mathrm{H}$; (d) soil settlement of $0.21 \mathrm{H}$.

settlement gradually increased from $16 \mathrm{~mm}$ to $33 \mathrm{~mm}$ as the embedded depth decreases. At the same time, the range of settlement influence has also significantly increased from the initial $60 \mathrm{~cm}$ to $120 \mathrm{~cm}$.

\section{Conclusions}

(1) The earth pressure in front of the pile increases linearly with the depth. The earth pressure in the bottom soil of the pit becomes smaller with the increase in excavation depth, but both are greater and lesser for static earth pressure and the passive earth pressure, respectively. The earth pressure behind the pile is almost linearly increased with the depth showing significant influence on embedded depth. The static earth pressure gradually approaches the active earth pressure with the decrease in embedded depth
(2) The overall deformation of the pile body is observed as a "big belly." The horizontal displacement of the pile body increases as the excavation depth increases, and the maximum displacement value decreases with the increase of the excavation depth; the smaller the solid depth, the greater will be the final horizontal displacement of the pile. The maximum value is declared as $1.2 \mathrm{~mm}, 0.22 \% \mathrm{H}$

(3) The ground settlement behind the pile gradually increases as the excavation progresses, and the maximum settlement position appears at approximately $0.5 \mathrm{H}$; with the reduction of the embedded depth, both the final settlement and the settlement influence range significantly increased

(4) It is recommended that the embedded depth for soldier piles in a pile-anchor supporting system in a granite residual soil area should not be less than $0.22 \mathrm{H}$ according to the results of horizontal 
displacement and settlement analysis and the "Shenzhen Area-Technical Code for Building Foundation Pit Support" 6.2.23 [24].

\section{Data Availability}

The data used to support the findings of this study are included within the article.

\section{Conflicts of Interest}

The authors declare that they have no conflicts of interest.

\section{Acknowledgments}

This research was funded by the National Natural Science Foundation of China (Nos. 41572257 and 41972267).

\section{References}

[1] W.-D. Hu, L.-X. Zeng, X.-H. Liu, and J. Liao, "Active earth pressures against rigid retaining walls for finite soil under the grading condition," Hydrogeology \& Engineering Geology, vol. 45, no. 6, pp. 63-70, 2018.

[2] W. D. Hu, X. N. Zhu, X. Y. Zhou, and J. Liao, "Experimental study on passive earth pressures of cohesionless soils with limited width against cantilever piles flexible retaining walls," Chinese Journal of Rock Mechanics and Engineering, vol. 38, no. 2, pp. 3748-3757, 2018.

[3] Y. W. Lei and G. Zheng, "Influence of partial over-excavation on safety performance of excavation retained by cantilever contiguous retaining piles," Journal of yangtze river scientifiv research institute, vol. 37, no. 9, pp. 70-78, 2020.

[4] D. J. Zuo and C. F. Deng, "Field test on mechanical properties and deformation characteristics of double-row piles with different embedded depths," Chinese Journal of Geotechnical Engineering, vol. 36, no. 2, pp. 355-359, 2014.

[5] H.-D. Gu and C. H. Luo, "Experiment on soil arching effect of pit supporting structure with scattered row piles and soil nail wall," Journal of Jilin University (Engineering and Technology Edition), vol. 48, no. 6, pp. 1713-1724, 2018.

[6] M. Li, J. M. Zhang, C. F. Lee, and G. Zhang, "Centrifuge model tests on a cohesive soil slope under excavation conditions," Soils and Foundations, vol. 51, no. 5, pp. 801-812, 2011.

[7] C. Zhou, X.-L. Hu, and W.-B. Zheng, "Displacement characteristic of landslides reinforced with flexible piles: field and physical model test," Journal of Mountain Science, vol. 17, no. 4, pp. 787-800, 2020.

[8] Y.-H. Wang, X.-Y. Liu, and S.-K. Sang, "A model test for the influence of lateral pressure on vertical bearing characteristics in pile jacking process based on optical sensors," Sensors (Basel, Switzerland), vol. 20, no. 6, pp. 1-14, 2020.

[9] D.-Z. Liu, X. Hu, C. Zhou, L. Li, C. He, and T. Sun, "Model test study of a landslide stabilized with piles and evolutionary stage identification based on thermal infrared temperature analysis," Landslides, vol. 17, no. 6, pp. 1393-1404, 2020.

[10] B.-X. Yuan, M. Sun, L. Xiong, Q. Luo, S. P. Pradhan, and H. Li, "Investigation of 3D deformation of transparent soil around a laterally loaded pile based on a hydraulic gradient model test," Journal of Building Engineering, vol. 28, p. 101024, 2020.
[11] Q.-X. Meng, H.-L. Wang, W.-Y. Xu, and M. Cai, "Multiscale strength reduction method for heterogeneous slope using hierarchical FEM/DEM modeling," Journal of Materials Research and Technology, vol. 115, p. 103164, 2021.

[12] Q.-X. Meng, H.-L. Wang, and W.-Y. Xu, "Numerical homogenization study on the effects of columnar jointed structure on the mechanical properties of rock mass," International Journal of Rock Mechanics and Mining Sciences, vol. 124, no. 6, pp. 104-127, 2019.

[13] J. Hyodo, Y. Tamari, and A. Sone, "A simplified method to consider the pile of insufficient length to obtain the support from bearing stratum," Journal of Asian Architecture and Building Engineering, vol. 19, no. 6, pp. 626-636, 2020.

[14] Z. Cui and Q.-M. Li, "Mechanical performance of composite retaining and protection structure for super large and deep foundation excavations," Journal of Civil Engineering and Management, vol. 25, no. 5, pp. 431-440, 2019.

[15] Y.-A. Liu, C.-M. Wang, X.-Y. Liu, and R.-Y. Gao, "Experimental study for the embedded depth of support structure foundation pit in granite residual soil area," Advances in Civil Engineering, vol. 2020, Article ID 6645942, 13 pages, 2020.

[16] F.-M. Wang and L.-L. Liu, "Deformation characteristics of supporting structure of deep foundation excavation in granite residual soil area," Construction Technology, vol. 48, no. 4, pp. 98-102, 2019.

[17] Q.-X. Meng, H. Wang, M. Cai, W. Xu, X. Zhuang, and T. Rabczuk, "Three-dimensional mesoscale computational modeling of soil-rock mixtures with concave particles," Engineering Geology, vol. 277, p. 105802, 2020.

[18] Y. Wang, B. Zhang, S. H. Gao, and C. H. Li, "Investigation on the effect of freeze-thaw on fracture mode classification in marble subjected to multi-level cyclic loads," Theoretical and Applied Fracture Mechanics, vol. 111, p. 102847, 2021.

[19] D.-W. Yin, S. Chen, Y. Ge, and R. Liu, "Mechanical properties of rock-coal bi-material samples with different lithologies under uniaxial loading," Journal of Materials Research and Technology, vol. 10, no. 6, pp. 322-338, 2021.

[20] X. Zheng, X.-W. Zhu, and Y.-J. Zhou, "Model tests study on deformation mechanism of double-row-piles wall," Building Structure, vol. 48, no. s1, pp. 763-767, 2018.

[21] G. Zheng, D.-Q. Qie, and X.-S. Cheng, "Experimental study on multi-bench retaining foundation pit," Chinese Journal of Geotechnical Engineering, vol. 39, no. 5, pp. 784-794, 2017.

[22] Shenzhen Housing and Local Construction Bureau, "SJG052011 Technical code for retaining and protection of excavations in shenzhen city," China Architecture \& Building, Press, Beijing, China, 2011.

[23] D.-Q. Tang and F. Yu, "Model excavation tests on double layered retaining structure composed of existing and supplementary soldier piles," Rock and Soil Mechanics, vol. 40, no. 3, pp. 1040-1049, 2019.

[24] Z. Li, S.-G. Liu, W.-T. Ren, J.-J. Fang, Q.-H. Zhu, and Z.L. Dun, "Multiscale laboratory study and numerical analysis of water-weakening effect on shale," Advances in Materials Science and Engineering, vol. 2020, Article ID 5263431, 14 pages, 2020. 